\title{
Pengaruh Pemberian Pupuk Kompos Jerami terhadap Pertumbuhan Dua Varietas Padi Gogo (Oryza sativa L.) pada Tanah Ultisol
}

\author{
The Effect of Straw Compost Fertilizer on the Growth of Two Gogo Rice Varieties \\ (Oryza sativa L.) in Ultisol Soil
}

\author{
Faridah $^{1}$, Erida Nurahmi ${ }^{1}$ dan Nurhayati ${ }^{1 *}$ \\ ${ }^{1}$ Jurusan Agroteknologi, Fakultas Pertanian, Universitas Syiah Kuala
}

\begin{abstract}
Abstrak. Penelitian ini dilaksanakan diTaman Teknologi Pertanian (TTP) Jantho Kecamatan Kota Jantho, Kabupaten Aceh Besar, dan Laboratorium Fisiologi Tumbuhan Fakultas Pertanian Universitas Syiah Kuala, yang berlangsung sejakbulan Agustus hingga Desember 2016. Penelitian ini menggunakan rancangan petak terpisah (split plot design), dengan dua faktor yaitu dosis pupuk kompos jerami dan varietas. Dosis pupuk kompos jerami menjadi petak utama yang terdiri atas 3 taraf yaitu (kontrol, 10 dan 20 ton ha- ${ }^{1}$ ), varietas menjadi anak petak yang terdiri atas 2 taraf yaitu (Situ Patenggang dan Sanbei). Peubah yang diamati meliputi tinggi tanaman, jumlah daun, jumlah anakan, dan berat berangkasan kering. Perlakuan dosis pupuk kompos jerami berpengaruh sangat nyata terhadap tinggi tanaman pada umur 4 dan 8 MST. Perlakuan varietas berpengaruh sangat nyata terhadap jumlah daun pada umur 4 dan 8 MST. Terdapat interaksi antara kompos jerami dan varietas terhadap jumlah anakan, jumlah daun dan berat berangkasan kering. Dosis pupuk kompos jerami yang terbaik terhadap pertumbuhan padi gogo pada tanah ultisol adalah 20 ton ha ${ }^{-1}$. Pertumbuhan padi gogo terbaik pada tanah ultisol dijumpai pada varietas sanbei. Kombinasi terbaik terhadap pertumbuhan padi gogo pada tanah ultisol adalah dosis pupuk kompos jerami 20 ton ha ${ }^{-1}$ dengan varietas sanbei.
\end{abstract}

Kata kunci : kompos jerami, varietas, pertumbuhan, padi gogo

\begin{abstract}
This research was conducted in the Agricultural Technology Park (ATP) of Jantho, Kota Jantho Subdistrict, Aceh Besar Regency, and Laboratory of Plant Physiology at the Faculty of Agriculture, Syiah Kuala University, which lasted from August to December 2016. The study used a split plot design, with two factors are doses of straw compost fertilizer and varieties. The doses of straw compost became the main plot consisting of 3 levels, namely (control, 10 and 20 tons ha $^{-1}$ ), the varieties being subplots consisting of 2 levels namely (Situ Patenggang and Sanbei). The variables observed included plant height, number of leaves, number of tillers, and dry weight. The treatment of straw compost doses significantly affected plant height at age 4 and 8 WAP. The treatment of varieties had a very significant effect on the number of leaves at ages 4 and 8 WAP. There were interactions between straw compost and varieties on the number of tillers, number of leaves and weight of dry stover. The best dose of straw compost for padigogo growth in ultisol soil is 20 tons $\mathrm{ha}^{-1}$. The best growth of upland rice on ultisol soil was found in sanbei varieties. The best combination of the growth of upland rice on ultisol soil is the dose of straw compost fertilizer 20 tons ha $^{-1}$ with varieties of sanbei.
\end{abstract}

Keywords: straw compost, varieties, growth, upland rice

\section{PENDAHULUAN}

Penduduk Indonesia yang terus bertambah dari tahun ke tahun dan pola pangan yang masih tergantung pada berasmembawa konsekuensi pada permintaan pangan yang berlanjut dalam jumlah besar. Tanaman padi yang biasanya diproduksi di lahansawah beririgasi teknis dengan tingkat kesuburan tanah cukup tinggi, karakteristik budidaya padi sawah seperti itu membatasi peluang untuk Meningkatan produksi beras karena lahan semakin sempit lahan cadangan untuk di jadikan sawah dan semakin ketatnya persainganpenggunaanair dengan industri, pertambangan, dan rumah tangga. Di sisi lain, konversi lahan sawah ke

Corresponding author: nurhayatibugis@unsyiah.ac.id

Jurnal Ilmiah Mahasiswa Pertanian - AGT, Vol. 4, No. 2, Mei 2019: 61-70 
nonpertanian makinsulit dikendalikan (Nazirah et al., 2015).Maka dari itu untuk memenuhi kebutuhan tersebut perlu dilakukan optimalisas ipemanfaatan sumberdaya lahan kering dan teknologi pengelolaannya dengan dikembangkan budidaya padi gogo (Barus, 2012).

Salah satu lahan kering yang memiliki pontesi adalah tanah ultisol karena memiliki luas yaitu sekitar 51 juta hektar (lebih kurang 29\% luas daratan Indonesia) (Munir, 1996). Tanah ultisol adalah tanah yang memiliki banyak permasalahan terkait kesuburan tanah. Tanah ultisol memiliki $\mathrm{pH}$ rendah, unsur $\mathrm{Al}, \mathrm{Fe}$, dan $\mathrm{Mn}$ tinggi yang menyebabkan unsure $\mathrm{P}$ tidak larut dan tidak tersedia bagi tanaman (Pirhat et al. 2015).

Upaya peningkatan produksi padi secara berkelanjutan perlu dilakukan dengan tetap mempertahankan kandungan bahan organik tanah melalui pemanfaatan kompos jerami. Kompos jerami padi dapat memperbaiki kondisi tanah menjadi lebih baik terutama ketersediaan hara seperti N, P,K,dan unsur-unsur hara mikro bagi tanaman (Nining, 2016)

\section{METODE PENELITIAN}

\section{Tempat dan Waktu Penelitian}

Penelitian ini dilaksanakan di Taman Teknologi Pertanian (TTP) Jantho Kecamatan Kota Jantho, Kabupaten Aceh Besar, dan Laboratorium Fisiologi Tumbuhan Fakultas Pertanian Universitas Syiah Kuala, berlangsung pada bulan Agustus - Desember 2016.

\section{Alat dan Bahan Penelitan}

Alat yang digunakan adalah hand tractor, meteran, timbangan analitik, oven, kamera hand phone dan alat tulis. Bahan yang digunakan dalam penelitian ini $15 \mathrm{~g}$ padi varitas Situ Patenggang, 15g padi varietas Sanbei, Pupuk kompos jerami sebanyak $54 \mathrm{~kg}$, dan pupuk dasar Urea $200 \mathrm{~kg} \mathrm{ha}^{-1}$ atau setara dengan $60 \mathrm{~g} / \mathrm{plot}, \mathrm{SP}-36150 \mathrm{~kg} \mathrm{ha}^{-1}$ atau setara dengan $45 \mathrm{~g} / \mathrm{plot}$, KCL $100 \mathrm{~kg} \mathrm{ha}^{-1}$ atau setara dengan $30 \mathrm{~g} / \mathrm{plot}$, kapas dan furadan.

\section{Rancangan penelitian}

Penelitian ini menggunakan rancangan petak terpisah (split plot design). Plot utama terdiri dari 3 taraf dosis pupuk kompos jerami, sedangkan anak petak terdiri dari 2 taraf varietas padi, diperoleh 6 kombinasi perlakuan dengan 3 ulangan sehingga terdapat 18 unit percobaan. Faktor pertama terdiri atas 3 taraf yaitu dosis pupuk kompos jerami (K), $\mathrm{K}_{0}=$ kontrol, $\mathrm{K}_{1}=10$ ton ha ${ }^{-1}$ dan $\mathrm{K}_{2}=20$ ton ha ${ }^{-1}$. Faktor kedua terdiri atas 2 taraf yaitu varietas padi $(\mathrm{V}), \mathrm{V}_{1}=$ Situ Patenggang dan $\mathrm{V}_{2}=$ Sanbei. Adapun kombinasi perlakuan antara dosis pupuk kompos dan varietas padi $\left(\mathrm{K}_{0} \mathrm{~V}_{1}, \mathrm{~K}_{0} \mathrm{~V}_{2}, \mathrm{~K}_{1} \mathrm{~V}_{1}, \mathrm{~K}_{1} \mathrm{~V}_{2}, \mathrm{~K}_{2} \mathrm{~V}_{1}, \mathrm{~K}_{2} \mathrm{~V}_{2}\right)$.

\section{Pelaksanaan Penelitian Perlakuan Benih}

Benih padi terlebih dahulu direndam dalam air yang jumlahnya 5 kali volume benih. selama $2 \times 24$ jam dengan air bersih, selanjutnya diangkat dan dibilas pada air mengalir. Kemudian benih diletakkan diatas kapas dan ditutup selama 2 x 24 jam sehingga 
keluar calon akar (radikula). Kemudian benih disemai dalam wadah plastik dengan tanah yang sudah dilumpurkan serta dicampurkan pupuk kompos jerami dengan perbandingan 5:1 (berdasarkan volume) selama 21 hari.

\section{Pengolahan Tanah dan Penanaman}

Persiapan lahan yaitu pembuatan bedengan atau plot sebanyak 18 plot, masingmasing plot berukuran $1,5 \mathrm{~m} \times 2 \mathrm{~m}$, dengan ukuran darinase $0,5 \mathrm{~m}$. Kemudian pemberian pupuk kompos jerami yang sesuai dengan perlakuan yaitu 6 plot diberikan pupuk kompos jerami dengan dosis $3 \mathrm{~kg} /$ plot atau setara 10 ton ha ${ }^{-1}, 6$ plot lainnya diberikan pupuk kompos jerami dengan dosis $6 \mathrm{~kg} /$ pot atau setara 20 ton $\mathrm{ha}^{-1}$, dengan cara menabur rata diatas plot kemudian dicangkul kembali untuk diratakan. Sedangkan 6 plot lainnya tidak diberikan kompos jerami (kontrol). Setelah dibiarkan selama 1x 24 jam barulah dilakukan penanaman dengan bibit yang berumur 21 hari setelah semai (HSS) dengan menanam satu bibit per lubang tanam pada jarak $25 \mathrm{~cm} \times 25 \mathrm{~cm}$.

\section{Pemeliharaan}

Pemelihraan tanaman yang dilakukan meliputi pengairan, penyulaman, penyiangan, Pemupukan dan pengendalian hama dan penyakit. Pengairan dilakukan jika tanah sudah terlalu kering yaitu dengan cara penyiraman yang dilaksanakan pada pagi hari mulai dari bibit ditanam sampai masa generatif. Penyulaman dilakukan apabila ada bibit yang tidak tumbuh setelah 7 hari dilakukan penanaman. Penyiangan gulma dilakukan sesuai pertumbuhan gulma dilapangan atau setiap 2 minggu sekali. Pemupukan dilakukan dengan takaran yang sama untuk setiap plot yang diuji. Pupuk diberikan dengan cara larikan. Pupuk dasar yang digunakan adalah pupuk Urea yaitu sebanyak $60 \mathrm{~g} / \mathrm{plot}$ setara dengan $200 \mathrm{~kg} \mathrm{ha}^{-1}$, SP-36 sebanyak 45g/plot setara dengan $150 \mathrm{~kg} \mathrm{ha}^{-1}, \mathrm{KCl}$ sebanyak 30g/plot setara dengan $100 \mathrm{~kg} \mathrm{ha}^{-1}$. Pupuk susulan pertama diberikan pada saat tanaman berumur 30 hari setelah tanam dengan menggunakan pupuk Urea sebanyak $60 \mathrm{~g} / \mathrm{plot}$ hal yang sama dilakukan saat pupuk susulan kedua yaitu tanaman berumur 45 hari setelah tanam, dengan menggunakan Urea sebanyak $60 \mathrm{~g} / \mathrm{plot}$. Pengendalian hama walang sangit yang menyerang padi pada saat masak susu yaitu dengan cara penyemprotan insektisida.

\section{Parameter Pengamatan}

Parameter yang diamati yaitu tinggi tanaman umur 4 dan 8 MST $(\mathrm{cm})$, jumlah anakan 4 dan 8 MST (batang), jumlah daun (helai) dan berangkasan kering (g).

\section{HASIL DAN PEMBAHASAN}

\section{Pengaruh Dosis Kompos jerami Terhadap Pertumbuhan Tanaman Padi Gogo Pada Tanah Ultisol}

Hasil uji $\mathrm{F}$ pada analisis ragam menunjukkan bahwa perlakuan dosis pupuk kompos jerami berpengaruh sangat nyata terhadap jumlah daun padi umur 4 dan 8 MST. 
Rata-rata jumlah daun padi akibat perlakuan dosis pupuk kompos jerami dapat dilihat pada Tabel 1.

Tabel 1. Rata-rata jumlah daun padi gogo akibat perlakuan dosis pupuk kompos jerami

\begin{tabular}{lccccc}
\hline \multirow{2}{*}{ Parameter yang diamati } & & \multicolumn{3}{c}{ dosis pupuk kompos jerami(ton ha $\left.^{-1}\right)$} & BNJ \\
\cline { 3 - 5 } & & 0 & 10 & 20 & 0,05 \\
\hline Jumlah daun (helai) & 4 MST & $58.17 \mathrm{~b}$ & $43.50 \mathrm{a}$ & $60.00 \mathrm{~b}$ & 9.74 \\
& $8 \mathrm{MST}$ & $106.67 \mathrm{~b}$ & $94.17 \mathrm{a}$ & $146.67 \mathrm{c}$ & 11.02 \\
\hline
\end{tabular}

Keterangan : Angka yang diikuti oleh huruf yang sama pada kolom yang sama menunjukkan tidak berbeda nyata pada $\mathrm{Uji}_{\mathrm{BNJ}} 0,05$

Tabel 1 menunjukkan jumlah daun tanaman padi akibat perlakuan dosis pupuk kompos jerami pada umur 4 nilaiterbanyak dijumpai pada dosis pupuk kompos jerami 20 ton $\mathrm{ha}^{-1}\left(\mathrm{~K}_{2}\right)$ yang berbeda nyata dengan perlakuan dosis 10 ton $\mathrm{ha}^{-1}\left(\mathrm{~K}_{1}\right)$ namun tidak berbeda nyata perlakuan Kontrol $\left(\mathrm{K}_{0}\right)$. Pada umur 8 MST nilai terbanyak dijumpai pada dosis pupuk kompos jerami 20 ton $\mathrm{ha}^{-1}\left(\mathrm{~K}_{2}\right)$ yang berbeda nyata dengan perlakuan lainnya.

\section{Pengaruh Varietas terhadap Parameter Pertumbuhan Tanaman Padi pada Tanah Ultisol}

Hasil uji $\mathrm{F}$ pada analisis ragam menunjukkan bahwa perlakuan varietas berpengaruh sangat nyata terhadap tinggi tanaman 4 dan 8 MST.

Rata-rata tinggi tanamanpadi akibat perlakuan varietas dapat dilihat pada Tabel 2.

Tabel 2. Rata-rata tinggi tanaman padi akibat perlakuan varietastanaman padi gogo pada tanah ultisol

\begin{tabular}{lcccc}
\hline \multirow{2}{*}{ Parameter yang diamati } & & \multicolumn{2}{c}{ Dua varietas } & BNT \\
\cline { 3 - 4 } & & Situ patenggang & Sanbei & 0,05 \\
\hline Tinggi tanaman $(\mathrm{cm})$ & $4 \mathrm{MST}$ & $61.71 \mathrm{~b}$ & $51.61 \mathrm{a}$ & 7.18 \\
& $8 \mathrm{MST}$ & $114.16 \mathrm{~b}$ & $103.38 \mathrm{a}$ & 6.32 \\
\hline
\end{tabular}

Keterangan : Angka yang diikuti oleh huruf yang sama pada kolom yang sama menunjukkan tidak berbeda nyata pada $\mathrm{Uji}_{\mathrm{BNJ}}{ }_{0,05}$

Tabel 2 menunjukkan bahwatinggitanaman padi akibat perlakuan varietas pada umur 4dan 8 MST nilai tertinggidijumpai pada varietas situ patenggang $\left(\mathrm{V}_{1}\right)$.

\section{Interaksi antara Dosis Pupuk Kompos jerami dan Dua varietas terhadap Parameter Pertumbuhan Tanaman Padi pada Tanah Ultisol}

\section{Jumlah Anakan}

Interaksi antara dosis pupuk kompos jerami kompos jerami dan dua varietas berpengaruh terhadap jumlah anakanpada pertumbuhan tanaman padi nilai jumlah anakan 
pada masing-masing dosis pupuk kompos jerami dan dua varietas disajikan pada gambar 1 dan 2

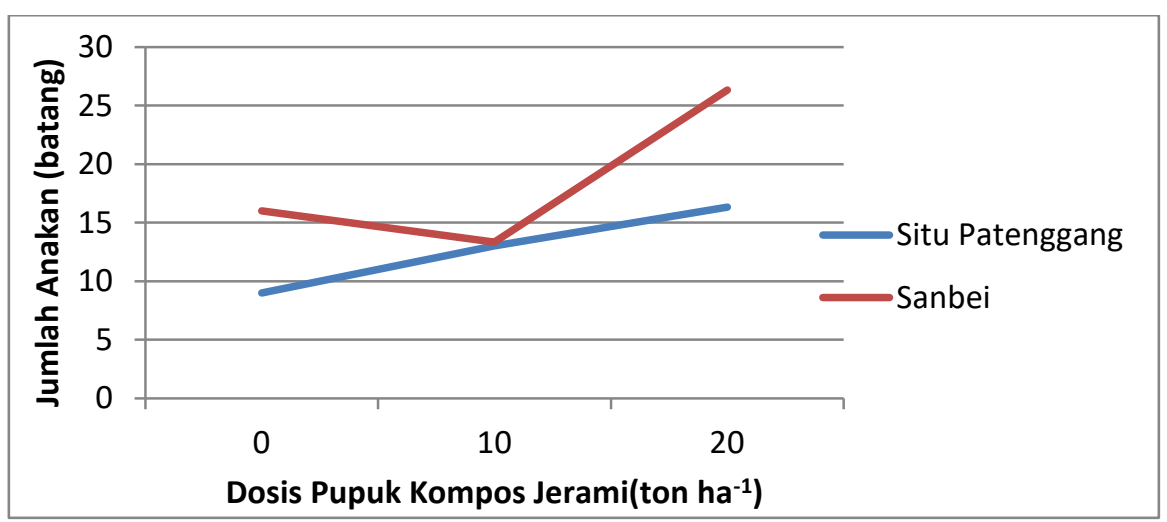

Gambar 1 Rata-rata jumlah anakan umu4 MST tanaman padi akibat perlakuan dosis pupuk kompos jerami dan dua varietas

Gambar 1 menunjukkan bahwa jumlah anakan umur 4 MST terbanyak dijumpai pada perlakuan dosis pupuk kompos jerami 20 ton ha ${ }^{-1}$ dengan varietas sanbei $\left(\mathrm{K}_{2} \mathrm{~V}_{2}\right)$ perlakuan dosis pupuk kompos jerami 20 ton $\mathrm{ha}^{-1}$ dengan varietas situpatenggang $\left(\mathrm{K}_{1} \mathrm{~V}_{1}\right)$. Selanjutnya pada perlakuan dosis pupuk kompos jerami 10 ton $\mathrm{ha}^{-1}$ dan kontrol tidak berbeda nyata pada kedua varietas tersebut.

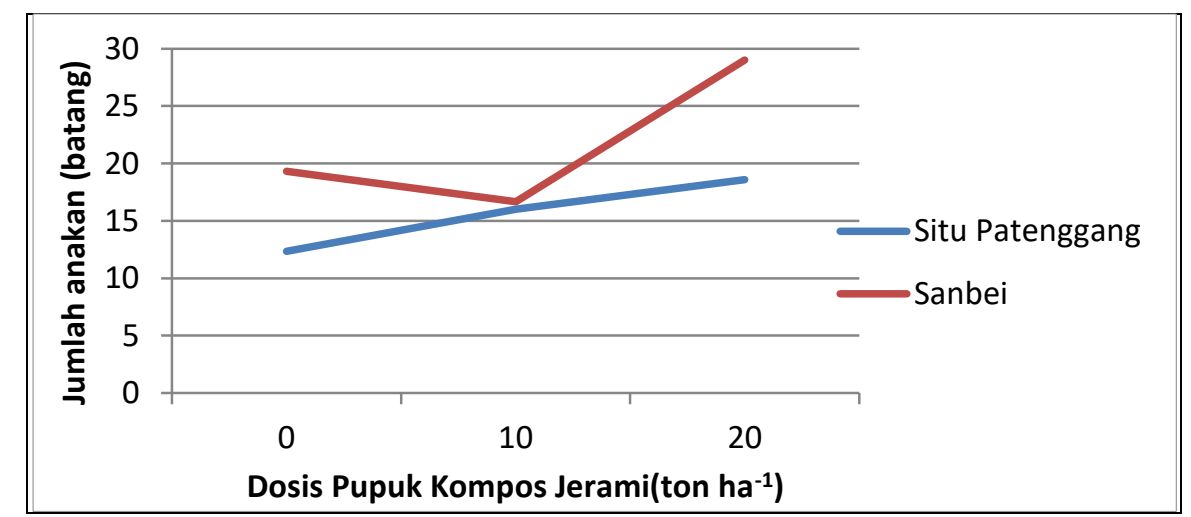

Gambar 2. Rata-rata jumlah anakan 8 MST tanaman padi akibat perlakuan dosis pupuk kompos jerami dan dua varietas

Gambar 2 menunjukan jumlah anakan umur 8 MST terbanyak dijumpai pada perlakuan dosis pupuk kompos jerami 20 ton ha ${ }^{-1}$ dengan varietas sanbei $\left(\mathrm{K}_{2} \mathrm{~V}_{2}\right)$ yang berbeda nyata dengan perlakuan dosis pupuk kompos jerami 20 ton $\mathrm{ha}^{-1}$ dengan varietas situpatenggang $\left(\mathrm{K}_{1} \mathrm{~V}_{1}\right)$. Selanjutnya pada perlakuan dosis pupuk kompos jerami 10 ton ha ${ }^{-1}$ dan kontrol tidak berbeda nyata pada kedua varietas tersebut. 


\section{Jumlah daun}

Interaksi antara dosis pupuk kompos jerami kompos jerami dan dua varietas berpengaruh terhadap jumlah daun, pada umur 4 dan 8 MST, pertumbuhan tanaman padi nilai jumlah daun pada masing-masing dosis pupuk kompos jerami dan dua varietas disajikan pada gambar 3 dan 4

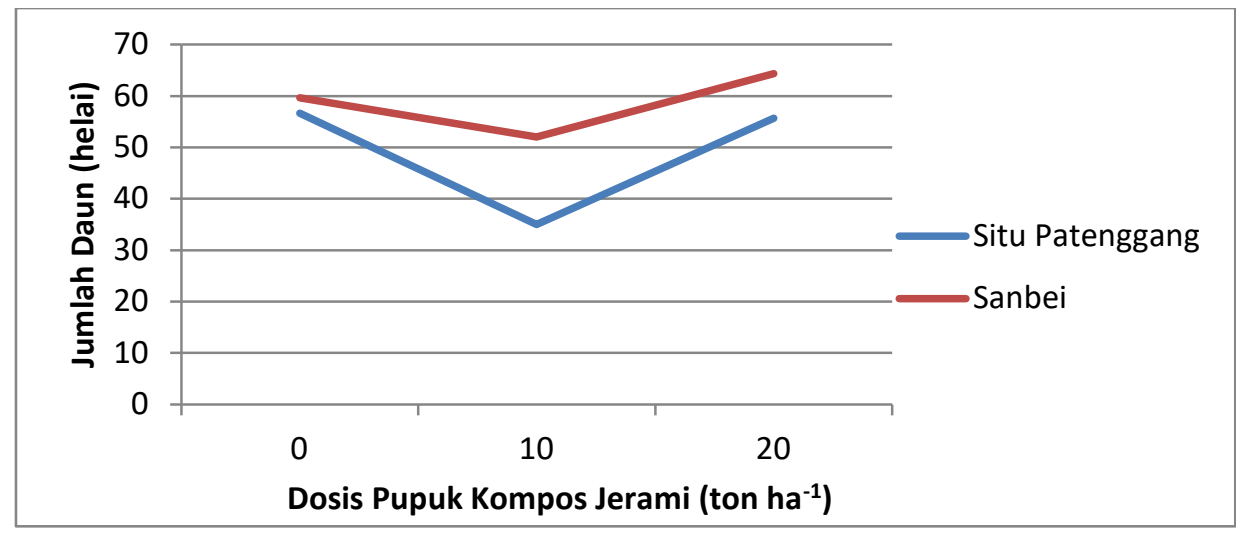

Gambar 3. Rata-rata jumlah daun 4 MST tanaman padi akibat perlakuan dosis pupuk kompos jerami dan dua varietas

Gambar 3 menunjukkan bahwa jumlah daunumur 4 MST terbanyak dijumpai pada perlakuan dosis pupuk kompos jerami 20 ton ha ${ }^{-1}$ dengan varietas sanbei $\left(\mathrm{K}_{2} \mathrm{~V}_{2}\right)$ yang berbeda nyata dengan perlakuan dosis pupuk kompos jerami 20 ton $\mathrm{ha}^{-1}$ dengan varietas situpatenggang $\left(\mathrm{K}_{1} \mathrm{~V}_{1}\right)$. Selanjutnya pada perlakuan dosis pupuk kompos jerami 10 ton ha ${ }^{-1}$ dan kontrol tidak berbeda nyata pada kedua varietas tersebut.

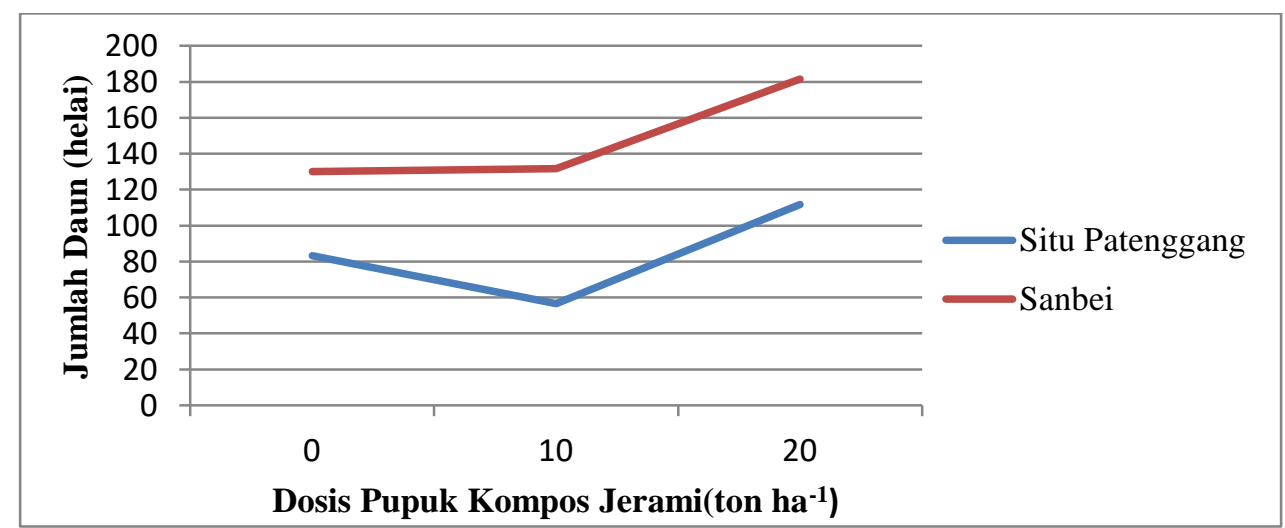

Gambar 4. Rata-rata jumlah daun 8 MST tanaman padi akibat perlakuan dosis pupuk kompos jerami dan dua varietas

Gambar 4 menunjukkan bahwa jumlah daun umur 8 MST terbanyak dijumpai pada perlakuan dosis pupuk kompos jerami 20 ton ha ${ }^{-1}$ dengan varietas sanbei $\left(\mathrm{K}_{2} \mathrm{~V}_{2}\right)$ yang berbeda nyata dengan perlakuan dosis pupuk kompos jerami 20 ton $\mathrm{ha}^{-1}$ dengan varietas 
situpatenggang $\left(\mathrm{K}_{1} \mathrm{~V}_{1}\right)$. Akan tetapi dosis pupuk kompos jerami 10 ton $\mathrm{ha}^{-1}$ dengan varietas sanbei tidak berbeda nyata pada perlakuan control dengan varietas sanbei.

\section{Berangkasan kering}

Interaksi antara dosis pupuk kompos jerami kompos jerami dan dua varietas berpengaruh terhadap berangkasan kering, pertumbuhan tanaman padi nilai berangkasan kering pada masing-masing dosis pupuk kompos jerami dan dua varietas disajikan pada gambar 5

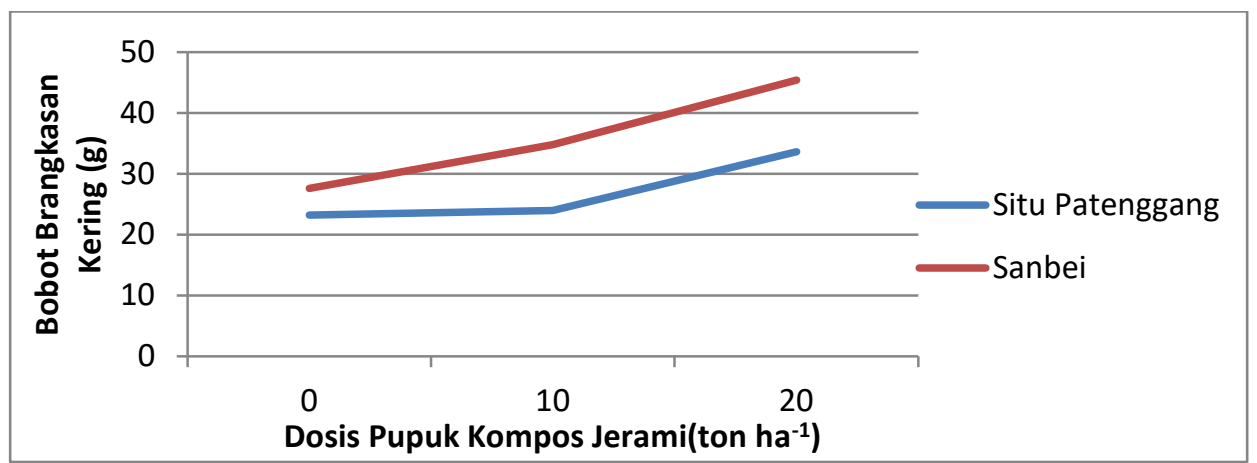

Gambar 5. Rata-rata jumlah berangkasan kering tanaman padi akibat perlakuan dosis pupuk kompos jerami dan dua varietas

Gambar 5 menunjukkan bahwa berat berangkasan kering tanaman padi tertinggi dijumpai pada perlakuan dosis pupuk kompos jerami 20 ton ha ${ }^{-1}$ dengan varietas sanbei $\left(\mathrm{K}_{2} \mathrm{~V}_{2}\right)$ yang berbeda nyata dengan perlakuan dosis pupuk kompos jerami 20 ton $\mathrm{ha}^{-1}$ dengan varietas situpatenggang $\left(\mathrm{K}_{1} \mathrm{~V}_{1}\right)$. Selanjutnya pada perlakuan dosis pupuk kompos jerami 10 ton ha ${ }^{-1}$ dan kontrol tidak berbeda nyata pada kedua varietas tersebut.

\section{Pembahasan}

\section{Pengaruh Dosis Kompos Jerami terhadap Parameter Pertumbuhan Tanaman Padi pada Tanah Ultisol}

Berdasarkan hasil penelitian menunjukkan bahwa perlakuan dosis kompos jerami pada dosis 20 ton ha ${ }^{-1}$ sangat berpengaruh pada parameter jumlah daun tanaman padi, hal inidikarena pengaruh bahan organik yang memiliki unsur hara mikro dalam membantu proses pertumbuhan dan penyerapan unsur hara secara optimal dan efektifdapat diserap dengan cepat bagi tanaman (Alavanet al.,2015)

Menurut Nyanjang et al., (2003) bahwa pemberian pupuk yang serimbang sangat mempengaruhi pertumbuhan dan hasil tanaman padi, karena dapat menambah dan mengembalikan unsur hara yang telah hilang baik tercuci maupun yang terbawa tanaman saat panen.

MenurutSarief (1986) ketersediaan unsur hara yang cukup untuk tanaman pada saat pertumbuhan dapat mengakibatkan fotosintesis berjalan lebih baik, dengan demikian 
proses pemanjangan, pembelahan dan diferensiasi sel akan terjadi lebih baik yang dapat mendukung pertumbuhan tanaman.

\section{Pengaruh Varietas terhadap Parameter Pertumbuhan Tanaman Padi pada Tanah Ultisol}

Berdasarkan hasil penelitian menunjukkan bahwa perlakuan varietas yang dicobakan sangat berpengaruh terhadap parameter tinggi tanaman. Pada perlakuan varietas pertumbuhan terbaik dijumpai pada varietas situ situ patenggang. Hal ini sesuai dengan penyataan Bakhtiar et al., (2013) situ patenggang merupakan varietas yang tinggi tanamannya lebih tinggi diantara varietas lain yang diteliti. Mawardi et al., (2016) juga mengumukakan bahwa varietas situ patenggang mempunyai tinggi tanaman yang lebih tinggi dibanding dengan varietas sanbei dan IR64. perbedaan tinggi tanaman yang terjadi antar varietas disebabkan karena varietas memiliki faktor genetik dan karakter yang berbeda, dengan kata lain adanya gen yang mengendalikan sifat dari varietas tersebut (Sugeng, 2001)

\section{Interaksi antara Dosis Pupuk Kompos jerami dan Dua varietas terhadap Parameter Pertumbuhan Tanaman Padi}

Berdasarkan hasil penelitian menunjukkan bahwa perlakuan varietas yang dicobakan sangat berpengaruh untuk tanaman padi, hal ini terlihat pada parameter jumlah anakan dan berat berangkasan kering.

Interaksi antara pupuk kompos jerami dengan varietas yang terbaik dijumpai pada kombinasi dosis pupuk kompos jerami 20 ton $\mathrm{ha}^{-1}$ dengan varietas sanbei terhadap jumlah daun dan jumlah anakan hal ini disebabkan karena pemberian kompos jerami dapat memperbaiki tanah ultisol baik sifat fisik, biologi dan kimia. Selanjutnya varietas anbei juga memiliki ketahanan terhadap stress kekeringan sehingga mampu tumbuh pada keadaan yang kritis hal ini juga didukung oleh Simanjuntak (2013), bahwa varietas lokal Sanbei memiliki potensi hasil yang tinggi, Setelah diuji dengan menanam secara SRI (System of Rice Intensification). Putra (2012) menyatakan bahwa pemberian pupuk baik itu jenis atau takaran sangat mempengaruhi respons tanaman padi sehingga berdampak terhadap pertumbuhan padi.

Menurut Gardner et al., (1991) faktor internal merupakan faktor yang dipengaruhi oleh sifat genetik atau sifat turunan yang dapat mempengaruhi tinggirendahnya pertumbuhan dan hasil tanamanseperti umur tanaman, morfologi tanaman, daya hasil, kapasitas menyimpan cadangan makanan, ketahanan terhadap penyakit. Faktor eksternal merupakan faktor lingkungan, seperti iklim, tanah dan factorbiotik. Perbedaan pertumbuhan dan hasil yang diperoleh dipengaruhi oleh satu atau lebih dari faktor tersebut.

Masdar et al., (2006), bahwa meningkatnya jumlah anakan juga dipengaruhi oleh faktor pemberian pupuk yang sesuai sehingga membantu proses pergerakan siklus makanan bagi pertumbuhan anakan, sebaliknya pemberian yang berlebihan dapat menekan pertumbuhan jumlah anakan. 


\section{BAB V. PENUTUP}

\subsection{Kesimpulan}

Dari hasil penelitian ini dapat di ambil beberapa kesimpulan yaitu:

1. Dosis pupuk kompos jerami berpengaruh terhadap semua parameter yang diamati, Pertumbuhan padi gogo terbaik pada tanah ultisol dijumpai pada dosis pupuk kompos jerami 20 ton $\mathrm{ha}^{-1}$.

2. Varietas berpengaruh terhadap tinggi tanaman, jumlah daun, jumlah anakan, dan berangkasan kering. Pertumbuhan padi gogo terbaik pada tanah ultisol dijumpai pada varietas sanbei $\left(\mathrm{V}_{1}\right)$

3. Terdapat interaksi antara perlakuan pupuk kompos jerami dan dua varietas terhadap jumlah daun, jumlah anakan dan bobot berangkasan kering. Pertumbuhan padi gogo terbaik pada tanah ultisol dijumpai pada kombonasi antara dosis pupuk kompos jerami 20 ton $\mathrm{ha}^{-1}$ dengan varietas Sanbei.

\subsection{Saran}

Perlu dilakukan penelitian lanjutan pemberian kompos jerami dengan dosis dan varietas yang berbeda hingga dapat meningkatkan produksi padi.

\section{DAFTAR PUSTAKA}

Alavan, A, R. Hayati dan E. Hayati. 2015. Pengaruh Pemupukan terhadap Pertumbuhan Beberapa Varietas Padi Gogo (Oryza Sativa L.). J.Floratek 10: 61 - 68.

Bakhtiar, Hasanuddin, T.Hidayat. 2013. Identifikasi BeberapaVarietas Unggul Padi Gogo di Aceh Besar. J.Agrista Vol. 17 (2).

Barus,J. 2012. Pengaruh Aplikasi Pupuk Kandang dan Sistim Tanam terhadap Hasil Varietas Unggul Padi Gogo pada Lahan Kering Masam di Lampung. Jurnal Lahan Suboptimal. Vol. 1(1) : 102-106.

Gardner, F. P., R. B. Pearce., R.Roger. dan L. Mitchell. 1991. Physiologyof Plant. Iowa State Universiti Press

Masdar, M. K., R. Bujang, H. Nurhayati dan Helmi. 2006. Tingkat Hasil dan Komponen Hasil Sistem Intensifikasi Padi (SRI) Tanpa Pupuk Organik di Daerah Curah Hujan Tinggi. Jurnal Ilmu Pertanian, Vol 8 (2). 126-131.

Mawardi, C.N. Ichsan, dan Syamsuddin. 2016. Pertumbuhan dan Hasil Beberapa Varietas Tanaman Padi (Oryza sativa L.) pada Tingkat Kondisi Kekeringan. JIM FP UNSYIAH, Vol. 1, No. 1, : 176-187.

Munir, H. M. 1996. Tanah-tanah Utama Indonesia Karakteristik, Klasifikasi dan Pemanfaatannya. PT Dunia Pusaka Jaya. Jakarta.

Nazirah, L., B. Sengli, J. Damanik. 2015. Pertumbuhan dan Hasil Tiga Varietas Padi Gogo pada Perlakuan Pemupukan. J. Floratek (10) :54 - 60.

Nining, S. S. 2016. Pengaruh Kompos Jerami Padi terhadap Pertumbuhan dan Hasil Tanaman Kailan (Brassica Alboglabra,L.) pada Tanah Podsolik Merah Kuning. J. Piper. Vol. 12. 
Nyanjang, R., A. A. Salim, Y. Rahmiati. 2003. Penggunaan Pupuk Majemuk NPK 25-7-7 terhadap Peningkatan Produksi Mutu pada Tanaman Teh Menghasilkan di Tanah Andisols. PT. Perkebunan Nusantara XII. Prosiding Teh.

Pirhat Nadiya, Idwar, A. N. Yulia. 2015. Pengaruh Amelioran dalam Mengefesienkan Penggunaan Pupuk pada Tanaman Padi Gogo (Oriza sativa L.) Varietas Situ Bagendit di Tanah Ultisol. Jurnal Online Mahasiswa FapertaVol. 2.

Putra, S. 2012. Pengaruh Pupuk NPK Tunggal, Majemuk, dan Pupuk Daun terhadap Peningkatan Produksi Padi Gogo Varietas Situ Patenggang. Agrotrop. Balai Pengkajian Teknologi Pertanian Jawa Barat. 2 (1) : 55-61.

Sarief, E. S. 1986. Kesuburan dan Pemupukan Tanah Pertanian. Pustaka Buana. Bandung.

Simanjuntak, H. R. 2013. Respon pertumbuhan dan produksi plasma nutfah padi (Oryza sativa L.) terhadap sistem budidaya SRI organik. Skripsi. Fakultas Pertanian. Universitas Syiah Kuala.

Sugeng, H. R. 2001. Bercocok Tanam Padi. CV Aneka Ilmu. Semarang 